\title{
En-Bloc Transurethral Resection of Non-Muscle- Invasive Bladder Cancer. Current Evidence and Glimpses into the Future
}

\author{
David D'Andrea ${ }^{1}$, Francesco Soria ${ }^{1,2}$, Kilian M Gust ${ }^{1}$, Paolo Gontero ${ }^{2}$, Rodolfo Hurle ${ }^{3}$, Thomas \\ RW Herrmann" ${ }^{4}$, Dmitry Enikeev ${ }^{5}$, Petr V Glybochko ${ }^{5}$, Sergey Kotov ${ }^{6}$, Maxim Ryabov ${ }^{6}$, Lukas \\ Lusuardi $^{7}$ and Shahrokh F Shariat ${ }^{1,5,8,9,10 *}$ \\ ${ }^{1}$ Department of Urology, Medical University of Vienna, Austria \\ ${ }^{2}$ Department of Surgical Sciences, AOU Città della Salute e della Scienza di Torino, Italy
}

${ }^{3}$ Department of Urology, Istituto Clinico Humanitas IRCCS, Italy

${ }^{4}$ Department of Urology, Kantonspital Frauenfeld, Switzerland

${ }^{5}$ Institute for Urology and Reproductive Health, I.M. Sechenov First Moscow State Medical University, Russia

${ }^{6}$ Department urology and andrology Pirogov Russian National Research Medical University, Russia

${ }^{7}$ Department of Urology, Paracelsus Medical University, Austria

${ }^{8}$ Department of Urology, University of Texas Southwestern Medical Center, USA

${ }^{9}$ Departments of Urology, Weill Cornell Medical College, USA

${ }^{10}$ Department of Urology, Charles University, Czechia

*Corresponding author: Shahrokh F Shariat, Department of Urology, Comprehensive Cancer Center, Medical University of Vienna, Währinger Gürtel 18-20, 1090 Vienna, Austria.

To Cite This Article: Shahrokh F Shariat. En-Bloc Transurethral Resection of Non-Muscle-Invasive Bladder Cancer. Current Evidence and Glimpses into the Future. Am J Biomed Sci \& Res. 2019 - 4(1). AJBSR.MS.ID.000756. DOI: 10.34297/AJBSR.2019.04.000756

Received: July 04, 2019 | Published: July 17, 2019

\section{Abstract}

Background: The purpose of this review was to summarize the current evidence on en-bloc transurethral resection (eTURB) of non-muscle-invasive bladder cancer compared to conventional TURB (CTURB) with a particular emphasis on ongoing randomized trials.

Materials and methods: A PubMed/MEDLINE search of the English-language literature from its inception until June 2019 using the following terms in isolation or combination "bladder cancer", "en bloc", "TURB" and "resection" was performed.

Evidence synthesis: Compared to CTURB, eTURB has been shown to achieve higher rates of detrusor muscle (>95\%) and better quality of the specimen for pathological evaluation. Complication rates and perioperative outcomes are comparable between the two techniques. Moreover, eTURB seems to achieve lower recurrence rates. However, the retrospective nature of the studies and underpowered prospective trials limit the interpretation of these results. There are currently two active randomized trials which are evaluating the one-year recurrence rate (EB-StaR) and difference in the rate of detrusor muscle in the specimen between cTURB and eTURB (eBLOC), respectively.

Conclusion: eTURB seems to provide a significant improvement in the surgical management of NMIBC with regards to oncology and safety outcomes.

Keywords: Bladder cancer; En-bloc; Transurethral resection

Abbrevations NMIBC: Non-Muscle-Invasive Bladder Cancer; TURB: Transurethral Resection of the Bladder; MIBC: Muscle-Invasive Bladder Cancer; BCG: Bacillus Calmette Guérin; RFS: Recurrence-Free Survival; PFS: Progression-Free Survival; OS: Overall Survival; eTURB: En-Bloc Transurethral Resection of the Bladder; cTURB: Conventional Transurethral Resection of the Bladder 


\section{Introduction}

Standard treatment of non-muscle-invasive bladder cancer (NMIBC) consists of transurethral resection of the tumor (TURB) with adjuvant intravesical instillation therapy, when needed, according to the tumor risk of recurrence and progression $[1,2]$. Despite adequate treatment, two thirds of patients will experience intravesical recurrence and one out of five will experience disease progression to muscle-invasive disease (MIBC) [3-a5].

The quality of the TURB determines the patients' prognosis and resulting treatment costs [1,6-10]. In a retrospective multiinstitutional cohort of 2,451 patients with T1G3/HG tumors treated with adjuvant bacillus Calmette Guérin (BCG), 935 patients received a re-TURB. The second resection improved recurrence-free survival (RFS), progression-free survival (PFS) and overall survival (OS) only in patients without muscle in the specimen from initial resection [11]. Moreover, it has been confirmed that the absence of detrusor muscle in the specimen is associated with a significantly higher risk of residual disease, early recurrence and tumor under staging [12]. Therefore, the presence of detrusor muscle in the specimen is considered as criteria for resection quality. Interestingly, two recent systematic reviews showed that residual tumor at re-TURB can be found in up to $67 \%$ of patients with Ta and in up to $71 \%$ with T1 $\mathrm{BC}$, even if muscle was present in the initial specimen $[13,14]$.In contrast, a retrospective multicenter analysis reported only $6.4 \%$ of residual cancer at re-TURB after en-bloc TURB (eTURB) for highrisk NMIBC [15].

Regardless of significant heterogeneity between studies, these data generate the hypothesis that conventional TURB (cTURB) resection technique does not guarantee a complete tumor removal resulting in residual disease while also limiting the pathologist ability to deliver an accurate pathological review due to the fragmented, charred and disoriented specimen. Indeed, cTURB of tumors larger than $1 \mathrm{~cm}$ requires fragmentation of the tumor which breaks the principles of oncologic handling. This results in multiple chips which may contain detrusor muscle, but do not allow a pathologic evaluation regarding resection margins, completeness of resection and orientation of the specimen. Therefore, there is an unmet need for improvement of resection techniques in order to better risk stratify and stage patients, reduce unnecessary interventions with risks (i.e. reTURB), improve patients' outcomes, and lower cost and burden of care [16-18]. In this context, eTURB is a novel method that promises to address these challenges of cTURB. Indeed, this technique has been shown to achieve higher rates of detrusor muscle ( $>95 \%$ ) and better quality of the specimen for pathological evaluation compared to CTURB in non-controlled studies [19]. eTRUB can be performed with several techniques. Most commonly used are laser fibers (thulium or holmium), hydro dissection (Hybrid knife) and electric slings [20,21]. The aim of this review was to summarize the current evidence on eTURB.

\section{Evidence acquisition}

We performed a PubMed/MEDLINE search of the Englishlanguage literature from its inception until June 2019 using the following terms in isolation or combination "bladder cancer", "en bloc", "TURB" and "resection". Reference lists in pertinent articles were reviewed to augment source material. Only prospective trials including $\geq 30$ patients were included.

In total, 10 articles were included in our analysis.

\section{Evidence synthesis}

\begin{tabular}{|c|c|c|c|c|c|c|c|}
\hline Author & Design & No of pts & T stage & Grade & $\begin{array}{c}\text { Presence } \\
\text { of detrusor } \\
\text { muscle }\end{array}$ & Residual tumor & Endpoints \\
\hline Lodde et al. [17] & Prospective, single arm & 37 & $\begin{array}{l}\text { pTa } 82.3 \% \\
\text { pT1 } 17.7 \%\end{array}$ & $\begin{array}{l}\text { G1 } 69.4 \\
\text { G2 } 16.1 \\
\text { G3 } 14.5\end{array}$ & NR & NR & Feasibility and safety \\
\hline Muto et al. [16] & Prospective, single arm & 55 & $\begin{array}{l}\text { Ta } 56.4 \% \\
\text { T1 } 32.7 \% \\
\text { T2 } 10.9 \% \\
\end{array}$ & $\begin{array}{l}\text { LG } 56.4 \% \\
\text { HG } 34.6 \%\end{array}$ & $100 \%$ & $\begin{array}{c}0 \% \\
\text { second look performed } \\
\text { within } 90 \text { days }\end{array}$ & $\begin{array}{l}\text { Perioperative out- } \\
\text { comes }\end{array}$ \\
\hline He et al. [19] & Prospective, single arm & 45 & $\begin{array}{l}\text { Ta: } 27 \\
\text { T1: } 15 \\
\text { T2a: } 3\end{array}$ & N. A. & $100 \%$ & NR & Feasibility and safety \\
\hline $\begin{array}{l}\text { Kramer et al. } \\
2015 \text { [18] }\end{array}$ & $\begin{array}{l}\text { Prospective multicenter, } \\
\text { multiarm, non-randomized }\end{array}$ & $\begin{array}{l}156 \text { electro } \\
\text { eTRUB } \\
65 \text { laser } \\
\text { eTURB }\end{array}$ & $\begin{array}{l}\text { Ta 83; T1 62; } \\
\text { T2 } 11 \\
\text { Ta 39; T1 26; } \\
\text { T2 } 0\end{array}$ & $\begin{array}{l}\text { LG 72; HG } 84 \\
\text { LG 33; HG } 32\end{array}$ & $\begin{array}{l}96.2 \% \\
100 \%\end{array}$ & $\begin{array}{l}\qquad 0 \% \\
\qquad 0 \% \\
\text { Evaluated by biopsies } \\
\text { from the margins at the } \\
\text { end of the procedure }\end{array}$ & $\begin{array}{l}\text { Staging quality mea- } \\
\text { sured by detrusor } \\
\text { muscle involvement, } \\
\text { various periopera- } \\
\text { tive parameters, and } \\
\text { 12-month follow-up } \\
\text { data }\end{array}$ \\
\hline
\end{tabular}




\begin{tabular}{|c|c|c|c|c|c|c|c|}
\hline Migliari et al. [23] & Prospective single arm & 58 & $\begin{array}{c}\text { Ta } 30 ; \text { T1 37; } \\
\text { T2 } 5\end{array}$ & LG 30; HG 37 & $100 \%$ & $\begin{array}{c}0 \% \\
\text { second look performed } \\
\text { within } 90 \text { days }\end{array}$ & $\begin{array}{c}\text { Feasibility and } \\
\text { comparison to a } \\
\text { historical cohort of } \\
61 \text { patients }\end{array}$ \\
\hline Chen et al. [14] & RCT & $\begin{array}{l}71 \text { cTURB } \\
71 \text { eTURB }\end{array}$ & $\begin{array}{l}\text { Tis 1; Ta 55; } \\
\text { T1 } 15 \\
\text { Tis 3; Ta 43; } \\
\quad \text { T1 } 25 \\
\end{array}$ & $\begin{array}{l}\text { LG 54; HG } 17 \\
\text { LG 48; HG } 23\end{array}$ & NR & NR & $\begin{array}{l}18 \text { months RFS, } p \\
=0.38\end{array}$ \\
\hline Liu et al. [15] & RCT & $\begin{array}{l}56 \text { cTURB } \\
64 \text { eTURB }\end{array}$ & $\begin{array}{c}\text { Ta } 60.7 \% ; \mathrm{T} 1 \\
39.4 \% \\
\text { Ta } 57.8 \% ; \mathrm{T} 1 \\
42.2 \%\end{array}$ & $\begin{array}{l}\text { LG 91.1\%; HG } \\
\text { 8.9\% } \\
\text { LG 89.1\%; HG } \\
10.9 \%\end{array}$ & NR & $\begin{array}{l}\qquad 0 \% \\
\qquad 0 \% \\
\text { Evaluated by biopsies } \\
\text { from the margins }\end{array}$ & RFS \\
\hline $\begin{array}{c}\text { Xishuang et al } \\
{[22]}\end{array}$ & $\begin{array}{l}\text { Prospective, three arms, } \\
\text { non-randomized }\end{array}$ & $\begin{array}{c}\text { eTURB: } 64 \\
\text { cTURB } \\
\text { (monop- } \\
\text { olar or } \\
\text { bipolar): } \\
109\end{array}$ & $\begin{array}{l}\text { Ta } 36 \text {; T1 23; } \\
\text { Tis } 5 \\
\text { Ta 65; T1 36; } \\
\text { Tis } 8\end{array}$ & $\begin{array}{l}\text { LG 44; HG } 20 \\
\text { LG 75; HG } 34\end{array}$ & NR & NR & Safety and efficiency \\
\hline Ukai et al. [25] & Prospective, single arm & 97 & $\begin{array}{c}\text { Ta } 30 ; \text { T1 60; } \\
\text { T2 } 7\end{array}$ & $\begin{array}{l}\text { G1 3; G2 46; } \\
\text { G3 } 48\end{array}$ & $82 \%$ & $\begin{array}{c}7 \% \\
\text { Defined as positive } \\
\text { deep margin at patho- } \\
\text { logic evaluation }\end{array}$ & $\begin{array}{l}\text { Accuracy of patho- } \\
\text { logical staging }\end{array}$ \\
\hline
\end{tabular}

Oncologic efficacy of en-bloc resection: While promising, the current body of evidence relies mainly on retrospective or prospective, nonrandomized studies (Table 1). Two prospective randomized trials compared RFS in eTURB performed with thulium laser resection with cTURB. No difference in RFS could be observed at 18 and 36 months ( $p=0.38$ and $p=0.89$, respectively) [22,23]. In the study by Liu et al., completeness of resection was evaluated by biopsies of the resection margins but in both studies the second look TURB data was omitted. Limitations of the procedure are inherent to tumor size, specimen retrieval and location of the tumor. Indeed, specimens beyond $3 \mathrm{~cm}$ in size cannot be removed in their entirety because of the limited urethral sheath diameter.

A retrospective multicenter series compared operative outcomes and RFS rates in 226 patients treated with laser eTURB (holmium or thulium) or electro eTURB (monopolar or bipolar). Both techniques were comparable with the main advantage of harvesting high quality specimens for pathological analysis with the detrusor muscle present in $97 \%$ of the cases [24]. This is consistent with most eTURB studies which reported high rates of detrusor muscle in the specimen [21,24-26]. In addition, a metaanalysis of seven retrospective studies with 886 patients, reported a significant difference in 24-moths RFS in favor of eTURB (odds ratio $0.66,95 \%$ confidence interval $0.47-0.92, p=0.02$ ) [27].

Safety and complications of en-bloc resection: It is assumed that eTURB has a complication profile comparable to cTURB. Nevertheless, current literature does not deliver sufficient evidence because of study heterogeneity and differences in complication assessments [27]. In general, eTURB seems to have less perforation and obturator nerve reflex rates compared to cTURB, is assumed to result from the higher cutting precision of this technique and the use of laser [15,23,28-31].

\begin{tabular}{|c|c|c|c|c|c|c|c|}
\hline $\begin{array}{l}\text { ClinicalTrials.gov } \\
\text { Identifier }\end{array}$ & Title & $\begin{array}{l}\text { Primary } \\
\text { outcome }\end{array}$ & No planned & $\begin{array}{c}\text { Experimental } \\
\text { arm }\end{array}$ & $\begin{array}{l}\text { Active Compar- } \\
\text { ator }\end{array}$ & Leading center & Status \\
\hline NCT02993211 & $\begin{array}{l}\text { Transurethral En Bloc Versus } \\
\text { Standard Resection of Blad- } \\
\text { der Tumour: A Multi-centre } \\
\text { Randomised Controlled Trial } \\
\text { (EB-StaR Study) }\end{array}$ & $\begin{array}{l}\text { One-year } \\
\text { recurrence } \\
\text { rate }\end{array}$ & 350 & Bipolar eTURB & Bipolar cTURB & $\begin{array}{c}\text { Caritas Medical } \\
\text { Centre } \\
\text { Hong Kong, } \\
\text { Hong Kong }\end{array}$ & Recruiting \\
\hline NCT02555163 & $\begin{array}{l}\text { Laser En Bloc Resection Of } \\
\text { Bladder Tumor (HoLERBT) VS. } \\
\text { Conventional Transurethral } \\
\text { Resection Of Bladder Tumors } \\
\text { (cTURBT) (HoLERBT) }\end{array}$ & $\begin{array}{l}\text { residual } \\
\text { disease at } \\
\text { re-staging } \\
\text { transurethral } \\
\text { bladder } \\
\text { biopsy }\end{array}$ & 100 & $\begin{array}{l}\text { Holmium (Ho: } \\
\text { YAG) Laser En } \\
\text { Bloc Resection } \\
\text { Of Bladder } \\
\text { Tumor }\end{array}$ & cTURB & $\begin{array}{l}\text { Urology and } \\
\text { Nephrology } \\
\text { Center in Man- } \\
\text { soura, Egypt. }\end{array}$ & $\begin{array}{l}\text { Not yet } \\
\text { Recruiting }\end{array}$ \\
\hline
\end{tabular}




\begin{tabular}{|c|c|c|c|c|c|c|c|}
\hline NCT02951078 & $\begin{array}{l}\text { A Study of Comparing Effects of } \\
\text { Thulium Laser en Bloc Resection } \\
\text { and Electrical Transurethral } \\
\text { Resection of the Non-muscle } \\
\text { Invasive Bladder Cancer }\end{array}$ & $\begin{array}{l}\text { The residual } \\
\text { rate of tumor } \\
\text { in the second } \\
\text { operation of } \\
\text { the two surgi- } \\
\text { cal methods }\end{array}$ & 172 & $\begin{array}{c}\text { Thulium Laser } \\
\text { eTURB }\end{array}$ & cTURB & $\begin{array}{l}\text { Shanghai Gen- } \\
\text { eral Hospital, } \\
\text { Shanghai Jiao } \\
\text { Tong Univer- } \\
\text { sity School of } \\
\text { Medicine }\end{array}$ & Unknown \\
\hline NCT03718754 & $\begin{array}{l}\text { En-bloc vs Conventional Resec- } \\
\text { tion of Primary Bladder Tumor } \\
\text { (eBLOC) }\end{array}$ & $\begin{array}{l}\text { Detrusor } \\
\text { muscle in the } \\
\text { specimen }\end{array}$ & 476 & $\begin{array}{l}\text { eTURB (all tech- } \\
\text { niques alloed) }\end{array}$ & cTURB & $\begin{array}{l}\text { Medical Univer- } \\
\text { sity of Vienna } \\
\text { Vienna, Austria }\end{array}$ & Recruiting \\
\hline NCT03221062 & $\begin{array}{l}\text { “En Bloc" Resection of NMIBC: } \\
\text { a Prospective? Single Cen- } \\
\text { tre? Randomized Study }\end{array}$ & $\begin{array}{l}\text { The patholog- } \\
\text { ical staging } \\
\text { assessment }\end{array}$ & 180 & $\begin{array}{l}\text { 1. Laser eTURB } \\
\text { 2. Hydroknife } \\
\text { eTURB }\end{array}$ & cTURB & $\begin{array}{l}\text { Tongji Med- } \\
\text { ical College } \\
\text { Huazhong } \\
\text { University } \\
\text { of Science \& } \\
\text { Technology }\end{array}$ & $\begin{array}{l}\text { Not yet } \\
\text { recruiting }\end{array}$ \\
\hline
\end{tabular}

eTURB = en-bloc TURB; cTURB = conventional TURB

Ongoing randomized trials: We identified five RCTs registered on ClinicalTrials.gov with two being active and recruiting patients (Table 2). The EB-StaR (NCT02993211) has as primary endpoint the one-year recurrence rate. A total 350 patients are planned to be recruited. It should be considered that the time frame of one year for recurrence rates is probably too short to demonstrate a statistically significant difference between the two groups. Therefore, this trial is likely to result in an underpowered analysis for this endpoint. The eBLOC (NCT03718754) aims to assess a difference in the rate of detrusor muscle in the specimen between cTURB and eTURB in 476 patients. This trial is powered for the primary endpoint. However, recurrence rate will be analyzed as secondary endpoint.

\section{Conclusion}

In summary, eTURB seems to provide a significant improvement in the surgical management of NMIBC with regards to oncology and safety outcomes. Nevertheless, the results of ongoing RCTs are required to assess its true value in tumor control and its potential to help reduce unnecessary re-TURB, eventually.

\section{Acknowledgements}

\section{None}

\section{Conflict of interest}

David D'Andrea reports a grant from the Austrian Urological Association for the conduction of the eBLOC study.

\section{References}

1. Babjuk M, Böhle A, Burger M, Capoun O, Cohen D, et al. (2017) EAU Guidelines on Non-Muscle-invasive Urothelial Carcinoma of the Bladder: Update 2016. Eur Urol 71(3): 447-461.

2. Xylinas E, Kent M, Kluth L, Pycha A, Comploj E, et al. (2013) Accuracy of the EORTC risk tables and of the CUETO scoring model to predict outcomes in non-muscle-invasive urothelial carcinoma of the bladder. Br J Cancer 109(6): 1460-1466.

3. Cambier S (2016) EORTC Nomograms and Risk Groups for Predicting Recurrence, Progression, and Disease-specific and Overall Survival in Non-Muscle-invasive Stage Ta-T1 Urothelial Bladder Cancer Patients Treated with 1-3 Years of Maintenance Bacillus Calmette-Gu'erin. Eur Urol 69: 60-69.

4. Abdollah F, Gandaglia G, Thuret R, Schmitges J, Tian Z, et al. (2013) Incidence, survival and mortality rates of stage-specific bladder cancer in United States: A trend analysis. Cancer Epidemiol 37(3): 219-225.
5. Svatek RS, Shariat SF, Novara G, Skinner EC, Fradet Y (2011) Discrepancy between clinical and pathological stage: external validation of the impact on prognosis in an international radical cystectomy cohort. BJU Int 107(6): 898-904.

6. Hansel DE, Amin MB, Comperat E, Cote RJ, Knüchel R, et al. (2013) A Contemporary Update on Pathology Standards for Bladder Cancer: Transurethral Resection and Radical Cystectomy Specimens. Eur Urol 63(2): 321-332.

7. Brausi M, Collette L, Kurth K, van der Meijden AP, Oosterlinck W, et al. (2002) Variability in the Recurrence Rate at First Follow-up Cystoscopy after TUR in Stage Ta T1 Transitional Cell Carcinoma of the Bladder: A Combined Analysis of Seven EORTC Studies. Eur Urol 41(5): 523-531.

8. Svatek RS, Hollenbeck BK, Holmäng S, Lee R, Kim SP, et al. (2014) The Economics of Bladder Cancer: Costs and Considerations of Caring for This Disease. Eur Urol 66(2): 253-262.

9. Sievert KD, Amend B, Nagele U, Schilling D, Bedke J, et al. (2009) Economic aspects of bladder cancer: what are the benefits and costs? World J Urol 27(3): 295-300.

10. Soria F, Marra G, D'Andrea D, Gontero P, Shariat SF (2018) The rational and benefits of the second look transurethral resection of the bladder for T1 high grade bladder cancer. Transl Androl Urology 8(1): 46-53.

11. Gontero P, Sylvester R, Pisano F, Joniau S, Oderda M, et al. (2016) The impact of re-transurethral resection on clinical outcomes in a large multicentre cohort of patients with T1 high-grade/Grade 3 bladder cancer treated with bacille Calmette-Guérin. BJU Int 118(1): 44-52.

12. Mariappan P, Zachou A, Grigor KM, Edinburgh Uro Oncology Group (2010) Detrusor Muscle in the First, Apparently Complete Transurethral Resection of Bladder Tumour Specimen Is a Surrogate Marker of Resection Quality, Predicts Risk of Early Recurrence, and Is Dependent on Operator Experience. Eur Urol 57(5): 843-849.

13. Cumberbatch MGK, Foerster B, Catto JWF, Kamat AM, Kassouf W, et al. (2018) Repeat Transurethral Resection in Non-muscle-invasive Bladder Cancer: A Systematic Review. Eur Urol 73(6): 925-933.

14. Naselli A, Hurle R, Paparella S, Buffi NM, Lughezzani G, et al. (2018) Role of Restaging Transurethral Resection for T1 Non-muscle invasive Bladder Cancer: A Systematic Review and Meta-analysis. Eur Urol Focus 4(4): 558-567.

15. Hurle R, Casale P, Lazzeri M, Paciotti M, Saita A, et al. (2019) En bloc re-resection of high-risk NMIBC after en bloc resection: results of a multicenter observational study. World J Urol 1-6.

16. Suarez Ibarrola R, Soria F, Abufaraj M, D’Andrea D, Preto M, et al. (2019) Surgical checklist impact on recurrence-free survival of patients with non-muscle-invasive bladder cancer undergoing transurethral resection of bladder tumour. BJU Int 123(4): 646-650. 
17. D Andrea D, Abufaraj M, Susani M, Ristl R, Foerster B, et al. (2018) Accurate prediction of progression to muscle-invasive disease in patients with pT1G3 bladder cancer: A clinical decision-making tool. Urol Oncol 36(5): 239.e1-239.e7.

18. D Andrea D, Moschini M, Gust K, Abufaraj M, Özsoy M, et al. (2017) Prognostic Role of Neutrophil-to-Lymphocyte Ratio in Primary Non-muscle-invasive Bladder Cancer. Clin Genitourin Cancer 15(5): e755-e764.

19. Kramer MW, Altieri V, Hurle R, Lusuardi L, Merseburger AS, et al. (2017) Current Evidence of Transurethral En-bloc Resection of Nonmuscle Invasive Bladder Cancer. Eur Urol Focus 3(6): 567-576.

20. Lodde M, Lusuardi L, Palermo S, Signorello D, Maier K, et al. (2003) En bloc transurethral resection of bladder tumors: use and limits. Urology 62(6): 1089-1091.

21. Muto G, Collura D, Giacobbe A, D Urso L, Muto GL, et al. (2014) Thulium:yttrium-aluminum-garnet Laser for En Bloc Resection of Bladder Cancer: Clinical and Histopathologic Advantages. Urology 83(4): 851-855.

22. Chen X, Liao J, Chen L, Qiu S, Mo C, et al. (2015) En bloc transurethra resection with 2-micron continuous-wave laser for primary nonmuscle-invasive bladder cancer: a randomized controlled trial. World J Urol 33(7): 989-995

23. Liu H, Wu J, Xue S, Zhang Q, Ruan Y, et al. (2013) Comparison of the safety and efficacy of conventional monopolar and 2-micron laser transurethral resection in the management of multiple nonmuscle-invasive bladder cancer. J Int Med Res 41(4): 984-992.

24. Kramer MW, Rassweiler JJ, Klein J, Martov A, Baykov N, et al. (2015) En bloc resection of urothelium carcinoma of the bladder (EBRUC):
European multicenter study to compare safety, efficacy, and outcome of laser and electrical en bloc transurethral resection of bladder tumor. World J Urol 33(12): 1937-1943.

25. He D, Fan J, Wu K, Wang X, Wu D, et al. (2014) Novel Green-Light KTP LaserEn BlocEnucleation for Nonmuscle-Invasive Bladder Cancer: Technique and Initial Clinical Experience. J Endourol 28(8): 975-979.

26. Naselli A, Introini C, Germinale F, Spina B, Puppo P (2012) En bloc transurethral resection of bladder lesions: a trick to retrieve specimens up to $4.5 \mathrm{~cm}$. BJU Int 109(6): 960-963.

27. Wu YP, Lin TT, Chen SH, Xu N, Wei Y, et al. (2016) Comparison of the efficacy and feasibility of en bloc transurethral resection of bladder tumor versus conventional transurethral resection of bladder tumor: A meta-analysis. Medicine 95(45): e5372.

28. Zhu Y, Jiang X, Zhang J, Chen W, Shi B (2008) Safety and Efficacy of Holmium Laser Resection for Primary Nonmuscle-Invasive Bladder Cancer Versus Transurethral Electroresection: Single-Center Experience. Urology 72(3): 608-612.

29. Xishuang S, Deyong Y, Xiangyu C, Tao J, Quanlin L, et al. (2010) Comparing the Safety and Efficiency of Conventional Monopolar, Plasmakinetic, and Holmium Laser Transurethral Resection of Primary Non-muscle Invasive Bladder Cancer. J Endourol 24(1): 69-73.

30. Migliari R, Buffardi A, Ghabin H (2015) Thulium Laser Endoscopic En Bloc Enucleation of Nonmuscle-Invasive Bladder Cancer. J Endourol 29(11): 1258-1262.

31. Herrmann TR, Wolters M, Kramer MW (2017) Transurethral en bloc resection of nonmuscle invasive bladder cancer. Curr Opin Urol 27(2): 182-1904 